\title{
ENHANCE PRODUCTION OF BLACK TIGER SHRIMP Penaeus monodon POSTLARVAE BY PROBIOTIC BACTERIUM Alteromonas sp.
}

\author{
Haryanti"), Ketut Sugama"), Seiichi Tsumura"*;), and Toshitaka Nishijima"***)
}

\begin{abstract}
Alteromonas sp. (coded as BY-9) bacterium isolated from the coastal water of Gondol Bali, Indonesia was purified and mass produced, then inoculated into the rearing media of Penaeus monodon larvae as a probiotic agent. Nauplii of Penaeus monodon were reared in concrete tanks capacity of $18 \mathrm{~m}^{3}$ each with a density of 100 nauplii/L. The larvae were reared with and without Alteromonas sp. up to stage 10 postlarvae. At day 18 the growth and survival rates of the larvae reared with Alteromonas sp. were significantly higher than in the control $(P<0.05)$. Probiotic treatment produced an those average survival rate of $44.90 \pm 8.30 \%$, whereas the control produced $10.15 \pm 1.91 \%$ survival rate. Application of Alteromonas $\mathrm{sp}$. bacterium strain at a density of $10^{6} \mathrm{cfu} / \mathrm{mL}$ to the culture media of larvae resulted in better growth of larvae and exhibited antagonistic activity against Vibrio, especially the luminous bacterium (Vibrio harveyi).
\end{abstract}

KEYWORDS: Alteromonas sp., Penaeus monodon, probiotic

\section{INTRODUCTION}

Farming the black tiger shrimp, Penaeus monodon, has considerable economic importance in Indonesia. It was estimated that in 1995 the production of cultured shrimp in the country was 80,000 metric tons, and the total number of postlarvae required for pond culture was about 6 billion per year (FAO, 1995). Ninety percent of the required postlarvae comes from hatcheries. Unfortunately, since 1991 hatcheries have faced epidemic outbreaks of the infectious luminous bacterium (Vibrio harveyi). A total of $70 \%$ the fry production failed due to these diseases (Rukyani, 1993; Lightner, 1996).

Most of the shrimp hatcheries apply specific management practices to prevent the outbreak of diseases. These include disinfecting the larval rearing water with chlorine, UV irradiation, ozone, improved filtering system, washing eggs, using clean natural feed, maintaining clean and hygienic hatcheries (Chamberlain, 1991; Garriques \& Arevalo, 1995). Despite these efforts, mass mortalities of larvae have frequently occurred, limiting the success of the shrimp hatcheries. Shrimp hatcheries routinely use antibiotics in order to prevent bacterial infection. At present there are 15 types of antibiotics have been used (Taslihan \& Kokarkin, 1994). Unfortunately, antibiotics have limited applicability, because bacterial pathogens have the ability to develop multiple antibiotic resistance (Riquelme et al., 1997). An alternative method to prevent the outbreak of diseases is to use probiotic preparations of non-pathogenic bacteria. It has been suggested that some probiotics produce chemical substances inhibitory to the bacterial pathogens.

Recently, some researchers have successfully used bacterial strains as biological control agents for larvae of the crab Portunus tuberculatus (Maeda \& Nogami; 1989; Maeda et al., 1992; Maeda, 1994; Maeda \& Liao, 1992; 1994). A strain of Vibrio alginoliticus was reported to be effective in reducing diseases of Penaeus vannamei larvae (Garriques \& Arevalo, 1995). Rengpipat et al. (1998) recently found that the probiotic bacterium Bacillus S11, applied to a $P$. monodon pond could increase the survival and growth of the shrimp. Riquelme et al. (1997) used Alteromonas haloplanktis bacteria as a potential probiotic strain in the culture of chilean scallop Argopecten purpuratus, which exhibited inhibitory effects against pathogenic Vibrio anguiliarum. The probiotic effect was examined by Douillet \& Langdon (1994) and Gibson et al. (1998), who observed a strain of bacterium (CA2) and Aeromonas media, strain A199, respectively enhanced the survival and growth of Pacific oyster, Crassostrea gigas larvae. Consequently, probiotics were considered a possible solution to disease problems, and a potential means to stabilize the production of black tiger shrimp P. 10 monodon postlarvae.

\footnotetext{
Researcher at the Gondol Research Institute Mariculture

- Research Center for Aquaculture

7 Japan Sea-Farming Association

Department of Aquaculture, Faculty of Agriculture, Japan
} 
The objective of this study was to determine the effect of the probiotic bacterium Alteromonas sp. on pathogens of black tiger shrimp $P$. monodon and their effect on the growth and survival of postlarvae.

\section{MATERIALS AND METHODS}

\section{Bacterium Strain}

The probiotic bacterium strain (Alteromonas sp.) isolated from the coastal waters near Gondol, Bali is a facultative anaerobe, gram-negative, yellow pigmented and rod type (Haryanti et al., 2000). This strain is heterophilic, with an optimum temperature growth temperature of $25^{\circ} \mathrm{C}$ (Haryanti, 1997) and coded as BY-9. The strain was selected after vibrio-static activity tests showed that BY-9 could suppress the growth of the pathogenic bacteria, Vibrio harveyi.

\section{Bacterial Culture}

The probiotic bacterium BY-9 was mass cultured following the method of Nogami and Maeda (1992). The culture media of the bacteria consisted of bacto peptone, bacto malt-extract, bacto yeast extract, and bacto soytone (product of DIFCO Lab) at concentrations of $0.05,0.1,0.05$, and $0.1 \%(\mathrm{w} / \mathrm{v})$ respectively, and in seawater at $\mathrm{pH} 7.6$ and at $25^{\circ} \mathrm{C}$. The bacterium BY -9 on Marine 2216E Agar slant was inoculated into test tubes containing $10 \mathrm{~mL}$ of sterile seawater using a platinum loop. A $2.5 \mathrm{~mL}$ bacterial suspension was inoculated into $50 \mathrm{~mL}$ culture media and incubated for $48 \mathrm{~h}$ at $25^{\circ} \mathrm{C}$. Three $10 \mathrm{~mL}$ aliquots of each $50 \mathrm{~mL}$ media culture were used to inoculate each of three sealed $10-\mathrm{L}$ glass flasks containing $9-\mathrm{L}$ of culture media. These cultures were incubated at $25^{\circ} \mathrm{C}$ for 48 $\mathrm{h}$, with aeration provided by the addition of $0.2-\mathrm{mm}$ filtered air to each flask. The bacterial culture was then added to the experimental larval rearing tanks.

\section{Maturation and Larval Rearing of Shrimp}

P. monodon spawners (average weight of $140.2 \pm$ $12.4 \mathrm{~g}$ and $83.6 \pm 7.4 \mathrm{~g}$, female and male respectively and $6.4 \pm 0.57 \mathrm{~cm}$ Carapace Length (female) and 4.9 $\pm 0.49 \mathrm{~cm}$ Carapace Length (male) were obtained from Sumbawa Island, Indonesia. The spawners were kept in an $8 \mathrm{~m}^{3}$ circular concrete tank with a recirculating water system of $70 \mathrm{~cm}$ water depth at a sex ratio of $1: 1$ and light intensity of 2-4 Ix with $12: 12$ day:night regime. The shrimp were fed daily at $15 \%$ body weight on a combination of squid, clam, and oyster with $2: 1: 1$ ratio. Spawning was induced by unilateral eyestalk ablation. Three days after ablation, matured females were transferred into a 500-L spawning tank. After spawning, the eggs were collected, washed, and kept in a hatching tank. Nauplii were disinfected by using
100 mg/L lodine (Argent Lab.) for 10 minutes before stocking into larval rearing tank. The larvae were fed with diatoms Skeletonema costatum at density of 5,000 cells $\mathrm{mL}^{-1}$ increasing gradually to $50,000-60,000$ cells $\mathrm{mL}^{-1}$ as larvae grew. Feeding was supplemented with a micro-encapsulated diet three times a day by adding $0.5 \mathrm{~g}, 1.0 \mathrm{~g}$, and $1.5 \mathrm{~g}$ per feeding time per $\mathrm{m}^{3}$ water culture for zoea, mysis, and postlarvae stages respectively. Shrimp larvae were fed Artemia salina twice daily at a density of 5 nauplii larvae ${ }^{-1}$ per feeding time, starting from mysis-3 and increasing up to 50 Artemia nauplii as larvae grew. Water exchanges of $25 \%$ to $50 \%$ were done daily from zoea- 3 to postlarvae stage. Culture water was maintained at $29-30^{\circ} \mathrm{C}$ and at 33-34 ppt salinity.

\section{Experimental Design and Data Analysis}

The experimental units were concrete tanks of 18 $\mathrm{m}^{3}$ capacity. Each treatment had six replicates randomly assigned. The treatment consisted of tanks without (control) and with probiotic bacterium BY-9 inoculum. Tanks were air-dried, filled with sea water and sterilized with $25 \mathrm{mg} / \mathrm{L}$ of $\mathrm{NaOCl}$ for $24 \mathrm{~h}$, aerated and neutralized with sodium thiosulphate. Initial stocking density was 100 nauplii $L^{-1}$. The cultured probiotic bacterium BY -9 was added daily to the larval rearing tank for 18 days, with an adjusted concentration of $10^{6}$ CFUmL ${ }^{1}$. The larvae were reared to stage 10 postlarvae. The shrimp larvae and water were sampled everyday to determine the growth and survival of larvae, and the effect of probiotic bacterium BY-9 on the population of Vibrio. An analysis of variance (ANOVA) was performed and Tukey's multiple range test used if the F statistic indicated significance $(P<0.05)$.

\section{RESULTS}

The survival of shrimp reared up to postlarvae-10 $(\mathrm{PL}-10)$ was significantly higher in the tanks inoculated with probiotic bacterium BY-9 $(44.90 \pm 8.30 \%)($ mean value) compared to that of control ( $10.15 \pm$ $1.91 \%$; Fig. 1A) $(P<0.05)$. The survival of larvae on zoea-1 to zoea-2 stage was high and they were not infected by luminous vibriosis yet. However, the larvae gradually died when reaching zoea-3 stage and some larvae failed moulting to mysis- 1 stage. In most cases, mass mortality occurred at those stages. The same result was obtained in the production of shrimp larvae (Fig. 1B). Based on these results, BY-9 bacteria have been adopted as a probiotic and biological control for the shrimp larvae $P$. monodon.

P. monodon larvae in the probiotic treatment grew faster compared to the control (Fig.2). The development of larvae to postlarvae-1, treated with bacterium BY -9 was 3-4 days earlier than for the control. Application of probiotic bacterium in the larval rearing of 


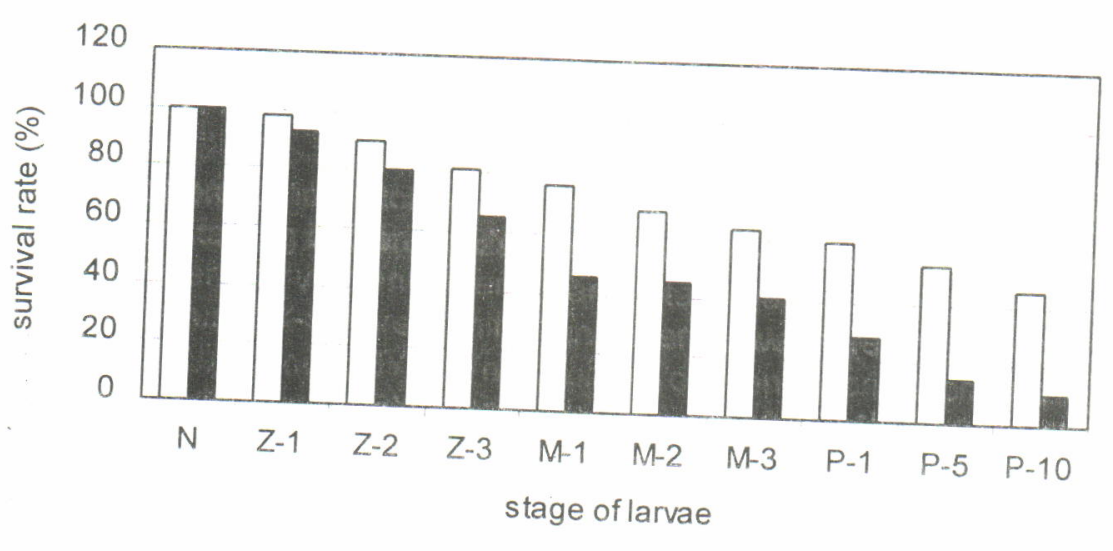

$\square$ With BY-9 Control

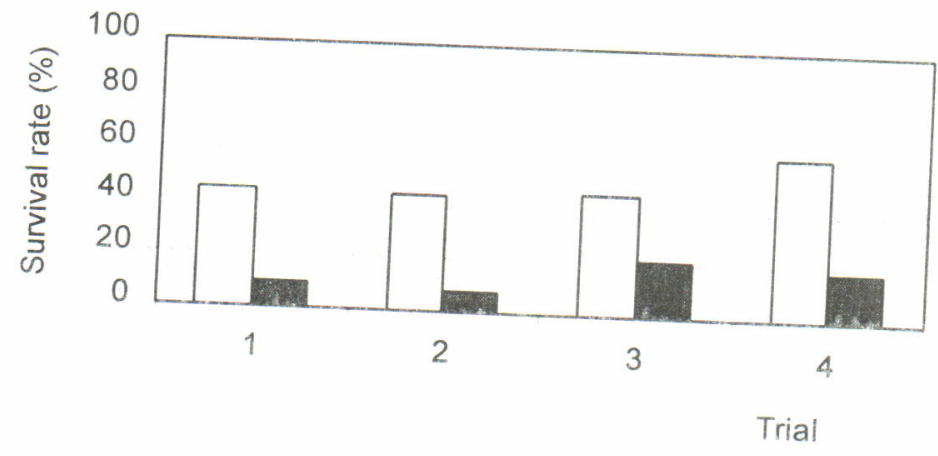

$\square$ With BY-9 Control

Figure 1. Survival rate of black tiger shrimp $P$. monodon postlarvae reared with and without Z: Zoea, M: Mysis, and P. Postlarvae and in 4 trials production (bottom). N: Nauplii,

shrimp gave effects to the stage development of zoea2 , of which $80 \%$ of larvae could develop to zoea-3 stage. In the control, the larvae stages of development were slower from zoea- 1 , of which $80 \%$ changed to zoea- 2 and $70 \%$ changed to zoea- 3 during 5 days rearing and continued till mysis and post larvae stage. All larvae reached the post-larvae-2 stage in 15 days

There was no significant difference in the total number of bacteria in the water containing bacterium $B Y$ 9 and control (Fig 3A). However, the Vibrio numbers in the water containing bacterium BY-9 were significantly lower that than without bacterium BY-9. The highest density of Vibrio with bacterium BY -9 was $10^{2} \mathrm{CFUmL}-1$, and no green and luminous colonies were detected, while in the control group, Vibrio bacteria reached $10^{4} \mathrm{CFUmL}^{-1}$ (Fig. $3 \mathrm{~B}$ ). Concerning this suppression ability, similar results were also obtained from other trials with application of bacterium BY-9 bacterium as probiotic agent for producing shrimp fry in hatcheries at Research Institute for Mariculture Gondol, which suggests that bacterium BY-9 could suppress the growth of Vibrio spp.

The effects of bacterium BY-9 on water quality were monitored during the rearing period. Dissolved oxygen $\left(5-6 \mathrm{mg} \mathrm{L}^{-1}\right), \mathrm{pH}(8.0-8.2)$, temperature $\left(28-29^{\circ} \mathrm{C}\right)$ and salinity (33-34 ppt) were recorded, and there were within acceptable ranges. The concentrations of phosphate (0.04-0.07 mg/L), nitrite (0.006-0.5 mg/L), nitrate (0.005-0.5 mg/L), ammonium (0.02-0.6 mg/L), and total organic matter (1.2-1.7 mg/L.) were similar in water between treatments and control, except for nitrate concentration which was higher with probiotic bacterium BY-9 (0.007-1.21 mg/L) than without bacterium $B Y-9(0.007-0.10 \mathrm{mg} / \mathrm{L})$

\section{DISCUSSION}

The application of probiotic bacterium BY-9 at a density of $10^{6} \mathrm{cfu} / \mathrm{mL}$ in the culture of shrimp larvae 

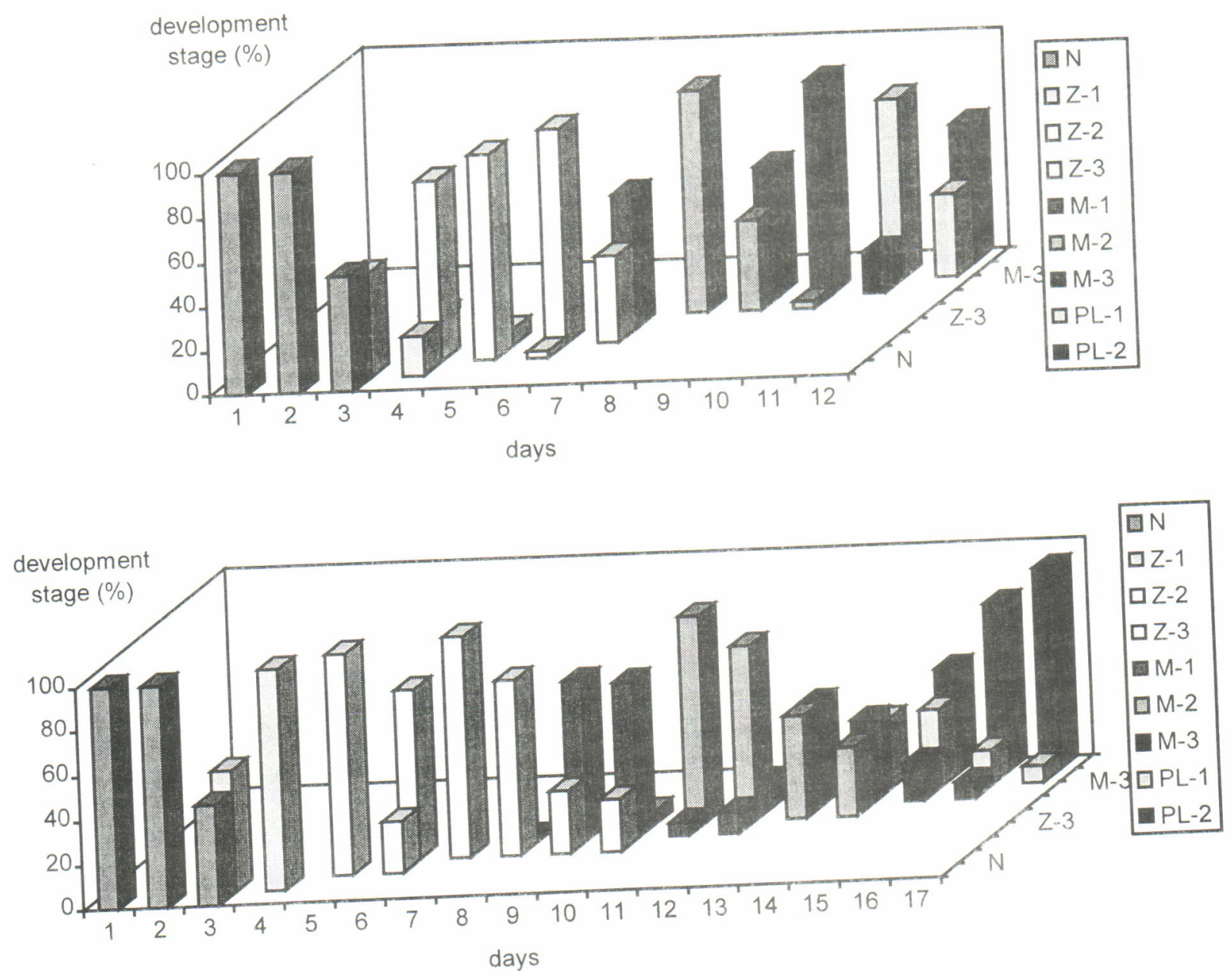

Developmental stage of black tiger shrimp $P$. monodon larvae reared with (upper) and without (bottom) bacterium BY-9. N: Nauplii, Z: Zoea, M:Mysis and PL: Postlarvae

clearly enhanced both growth and survival of $P$. monodon postlarvae. The growth and survival of larvae were similar up to the zoeal stage, but showed differences after mysis and post-larvae stage. There are several mechanisms by which probiotics applied in hatcheries may cause their effects such as, competitive exclusion of pathogenic bacteria, enhanced nutrition by supplying essential nutrients, enhanced digestion by supplying essential enzymes, direct uptake of dissolved organic material mediated by the bacteria, and production of substances that inhibit the growth of opportunistic pathogens (Garriques \& Arevalo, 1995).

Holt et al. (1984) reported that some strains of the genus Alteromonas, the same genus with bacterium BY-9 strain in the present study produced a polyanionic, autotoxic antibiotics on complex media and may also produce bactericidal brominated compounds. The inhibitory agent, called bacteriocin-like inhibitory substances (BLIS) produced by Aeromonas media has been reported as a probiotic agent on $\mathrm{Pa}$ cific oyster Crassostrea gigas (Gibson et al., 1998).

One serious problem in the seed production of black tiger shrimp is the outbreak of luminous vibriosis disease, caused by $V$. harveyi, for which antibiotics have been widely used. However, the indiscriminate use of antibiotics could create various problems such as disturbing the natural dynamic balance of the microbial floral in the system and may lead to the development of resistant pathogenic bacteria strains. The application of bacterium BY -9 bacteria could reduce or eliminate the used of antibiotics. Two possible reasons exist to explain why the population of Vibrio spp. was low when bacterium BY-9 was added. One is the production of vibriostatic activity substance by bacterium BY-9, and the other is niche competition between Vibrio bacteria and bacterium BY-9.

Our results indicates that the effect of using probiotic bacterium in the rearing of $P$. monodon larvae is to inhibit the pathogenic bacteria $V$. harveyi and 


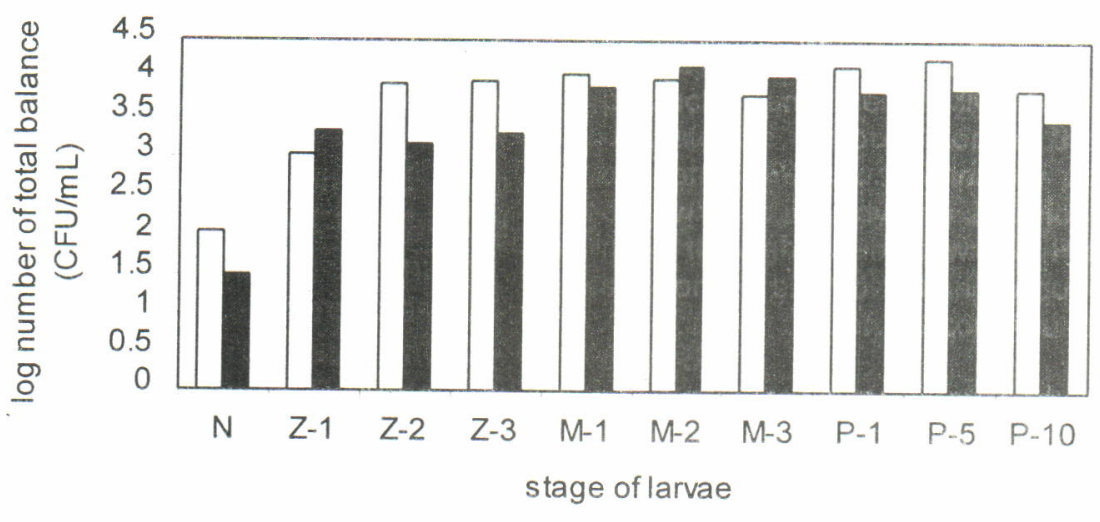

$\square$ With BY-9 Control

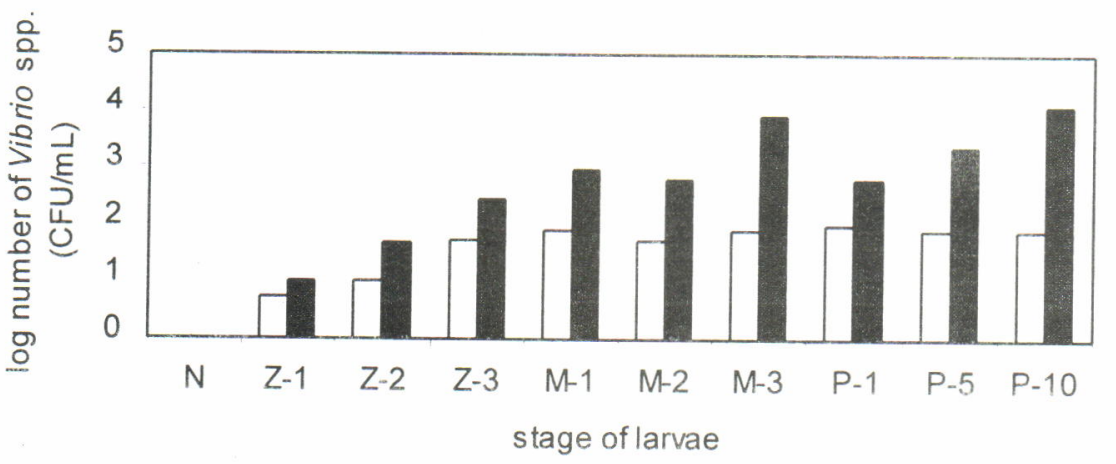

$\square$ With BY-9 Control

Figure 3. Total bacteria (upper) and Vibrio spp. (bottom) in the rearing water of $P$. monodon larvae with and without bacterium BY-9. N: Nauplii, Z:Zoea, M:Mysis and P:Postlarvae

to promote the growth and survival of shrimp larvae. The ability of the probiotic bacteria in manipulating the bacterial floral of the larval rearing system has promising applications in aquaculture, and is a feasible alternative for the sustainability of the shrimp industry.

\section{ACKNOWLEDGMENT}

The authors are grateful to Gufron Arif, Putu Suarjana, Kadek Mastantra, Suri Adyani, Usman and Luh Yuliawati for their help in the rearing and maintenance of $P$. monodon larvae. This research was supported by Agency for Agricultural Research and Development, Department of Agriculture, The Republic of Indonesia.

\section{REFERENCES}

Chamberlain, G.W. 1991. Seedstock production. World Aquaculture 22(3): 51-57.
Douillet, P.A. and C.J. Langdon. 1994. Use of a probiotic for the culture of larvae of the Pacific oyster (Crassostrea gigas Thunberg). Aquaculture 119: 2540.

FAO.1995. Aquaculture production statistics 1984-1993. FAO Fisheries Circular No. 815, Rome Italia. 56 pp.

Garriques, D. and G. Arevalo. 1995. An evaluation of the production and use of a live bacterial isolate to manipulate the microbial flora in the commercial production of Penaeus vannamei postlarvae in Ecuador. In: C.L. Browdy and J.S. Hopkins (eds.). Swimming through troubled water. Proc. of the special session on shrimp farming. Aquaculture '95. World Aquaculture Society, Baton Rouge, Louisiana, USA. p: $53-59$.

Gibson,L.F., J. Woodworth, and A.M. George. 1998. Probiotic activity of Aeromonas media on the Pacific oyster, Crassostrea gigas, when challenged with Vibrio tubiashi. Aquaculture 169: 111-120.

Haryanti, S. Lante, dan S. Tsumura. 1997. Studi pendahuluan penggunaan bakteri Flavimonas BY-9 sebagai probiotik dalam pemeliharaan larva udang 
windu Penaeus monodon. Jurnal Penelitian Perikanan Indonesia III (1):44-52.

Haryanti, K. Sugama, S. Tsumura and T. Nishijima. 2000. Vibriostatic Bacterium Isolated from Seawater: Potentiality as Probiotic Agent in the Rearing of Penaeus monodon larvae. IFRJ. 6(1): 26-32.

Holt, J.G., N.R. Krieg, P.H.A. Sneath, J.T. Staley, and S.T. William. 1984. Facultative anaerobic Gram negative rods. In N.R.Krieg and J.G. Holt, (eds.) Bargey's Manual of Systematic Bacteriology . p: 343-352.

Lightner,D.V. 1996. A Handbook of shrimp pathology and diagnostic procedures for diseases of cultured penaeid shrimp. World Aquaculture Society, Lausiana, USA. $305 \mathrm{pp}$.

Maeda,M. 1994. Biocontrol of the larval rearing biotop in aquaculture. Bulletin National Research Institute of Aquaculture 1:71-74.

Maeda,M. and K.Nogami. 1989. Some aspects of the biocontrolling method in aquaculture. In S. Miyachi, I. Karube and Y. Ishida,(eds.). Current Topics in Marine Biotechnology. Japan Society Marine Biotechnology, Tokyo. p:395-398.

Maeda,M., K. Nogami and N. Ishibashi. 1992. Utility of microbial food assemblages for culturing a crab, Portunus trituberculatus. Bulletin National Research. Institute of Aquaculture 21:31-38.

Maeda,M. and I.C. Liao. 1992. Effect of bacterial population on the growth of prawn larvae Penaeus monodon.
Bulletin National Research Institute of Aquaculture 21: 25-29.

Maeda,M. and I.C. Liao. 1994. Microbial processes in aquaculture environment and importance for increasing crustacean production. JARQ 28(4): 283-288.

Nogami, K. and M. Maeda. 1992. Bacteria as biocontrol agent for rearing larvae of the crab Portunus trituberculatus. Canadian Journal of Fisheries and Aquatic Science 49 (11): 2373-2376.

Rengpipat,S., W. Phianphak, S. Piyatiratitivorakul, and P. Menasveta. 1998. Effect of a probiotic bacterium on black tiger shrimp Penaeus monodon survival and growth. Aquaculture 167: 301-313

Riquelme, C., R.Araya, N. Vergara, A. Rojas, M. Guaita, and M. Candia. 1997. Potential probiotic strains in the culture of the Chilean scallop Argopecten purpuratus (Lamarck, 1819). Aquaculture 154: 1726.

Rukyani, A. 1993. The status of aquaculture and fish disease problems in Indonesia. Presented at an International Workshop on Quick Diagnostic Methods and Bioecological Control of Fish and Fish Diseases, Hanoi, Vietnam, 28 July - 7 August 1993. 8 pp.

Taslihan,A. and C. Kokarkin. 1994. Status of antibiotic in shrimp hatchery. Presented at Workshop on Coastal Environmental Management for Sustainable Aquaculture, Bali, Indonesia 31 October - 4 November 1994. $12 \mathrm{pp}$. 